\title{
We are stardust
}

Citation for published version (APA):

Haenen, G. R. M. M. (2018). We are stardust. Maastricht University. https://doi.org/10.26481/spe.20180112gh

Document status and date:

Published: 12/01/2018

DOI:

10.26481/spe.20180112gh

Document Version:

Publisher's PDF, also known as Version of record

\section{Document license:}

Unspecified

\section{Please check the document version of this publication:}

- A submitted manuscript is the version of the article upon submission and before peer-review. There can be important differences between the submitted version and the official published version of record.

People interested in the research are advised to contact the author for the final version of the publication, or visit the DOI to the publisher's website.

- The final author version and the galley proof are versions of the publication after peer review.

- The final published version features the final layout of the paper including the volume, issue and page numbers.

Link to publication

\footnotetext{
General rights rights.

- You may freely distribute the URL identifying the publication in the public portal. please follow below link for the End User Agreement:

www.umlib.nl/taverne-license

Take down policy

If you believe that this document breaches copyright please contact us at:

repository@maastrichtuniversity.nl

providing details and we will investigate your claim.
}

Copyright and moral rights for the publications made accessible in the public portal are retained by the authors and/or other copyright owners and it is a condition of accessing publications that users recognise and abide by the legal requirements associated with these

- Users may download and print one copy of any publication from the public portal for the purpose of private study or research.

- You may not further distribute the material or use it for any profit-making activity or commercial gain

If the publication is distributed under the terms of Article $25 \mathrm{fa}$ of the Dutch Copyright Act, indicated by the "Taverne" license above, 


\section{Maastricht University}

Prof. Dr. Guido R.M.M. Haenen

Faculty of Health, Medicine and Life Sciences

\section{We are stardust}

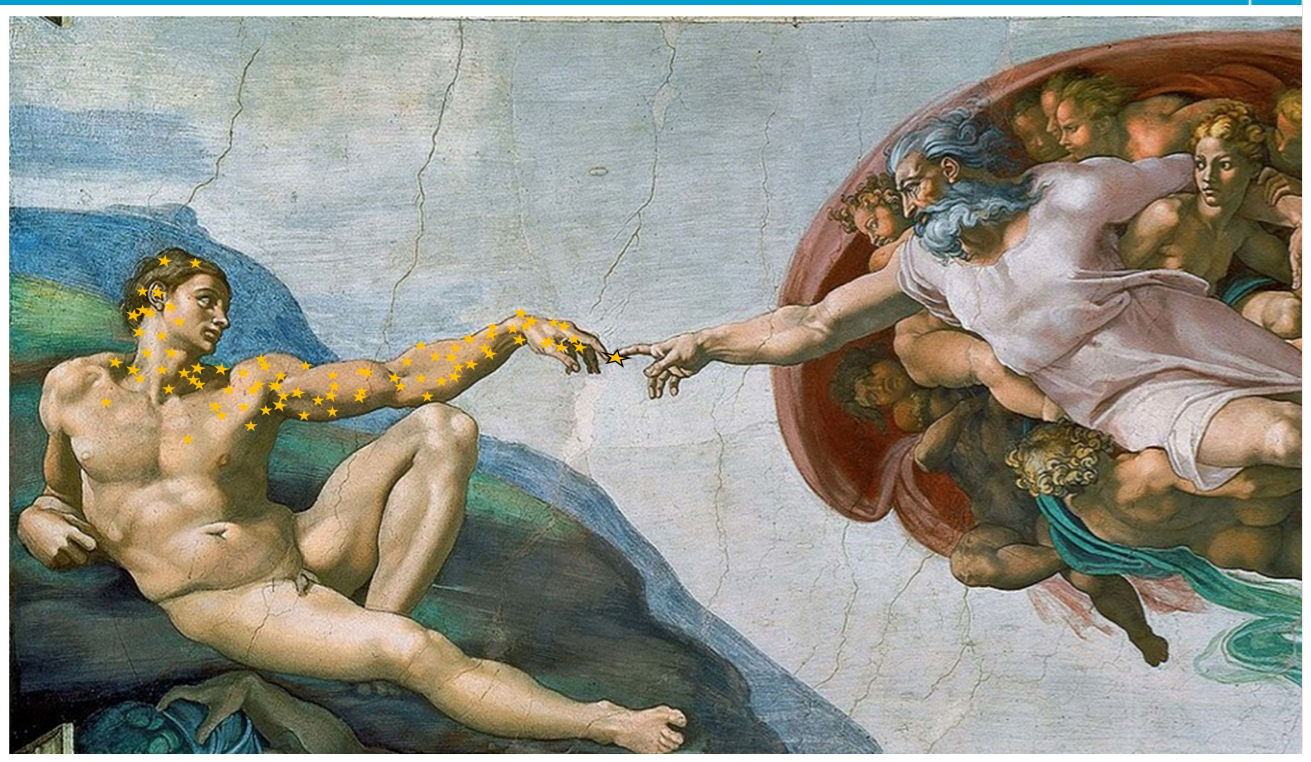




\section{We are stardust}

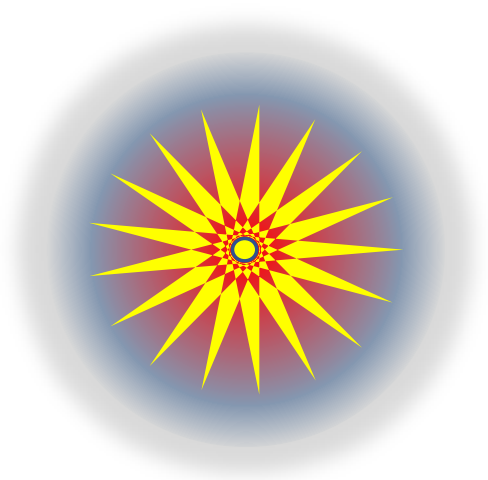

Uitgesproken bij de aanvaarding van het ambt van hoogleraar "Redox Modulation of Pharmacological and Toxicological Processes" aan de Faculty of Health, Medicine and Life Sciences, Maastricht University

Maastricht 12-01-2018

Prof. dr. Guido R.M.M. Haenen

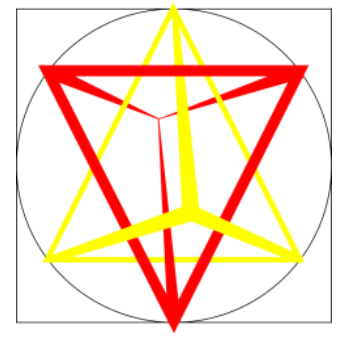

The dream I dream alone is only of comfort to me, the dream we dream together will become reality.

Aan Myriam, Jan en Suzanne. 
Geachte rector, collega's, familie en vrienden. Hartelijk dank dat u allen vandaag bij mijn oratie aanwezig wilt zijn, waar ik mij aan u voorstel en officieel mijn leerstoel, getiteld:

"Redox modulation of pharmacological and toxicological processes" aanvaard. Ik zal in mijn oratie mijn vakgebied proberen uit te leggen en proberen aan te geven wat mijn visie is.

Maar ik begin met mezelf als wetenschapper.

Ik begon al jong. In deze jeugdfoto, die mij erg dierbaar is, ziet $u$ de jonge onderzoeker die vol verwondering de wereld inkijkt en daar duidelijk van geniet. Het is de koninklijke kunst om die onbevangen verwondering te behouden en dit zaadje dat in mij is geplant, te koesteren en te laten groeien met alles wat ik in mijn leven tegenkom. En je kunt heel wat tegenkomen in je leven, zoals afgebeeld in het bekende schilderij van Jheronimus Bosch, De Tuin der Lusten. We kunnen alleen maar hopen dat we geluk hebben en

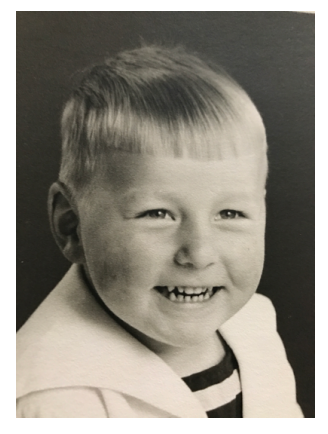
alles goed gaat zodat we na onze dood uiteindelijk uitkomen in het Hof van Eden, en gespaard blijven voor het eeuwig branden in de Hel.
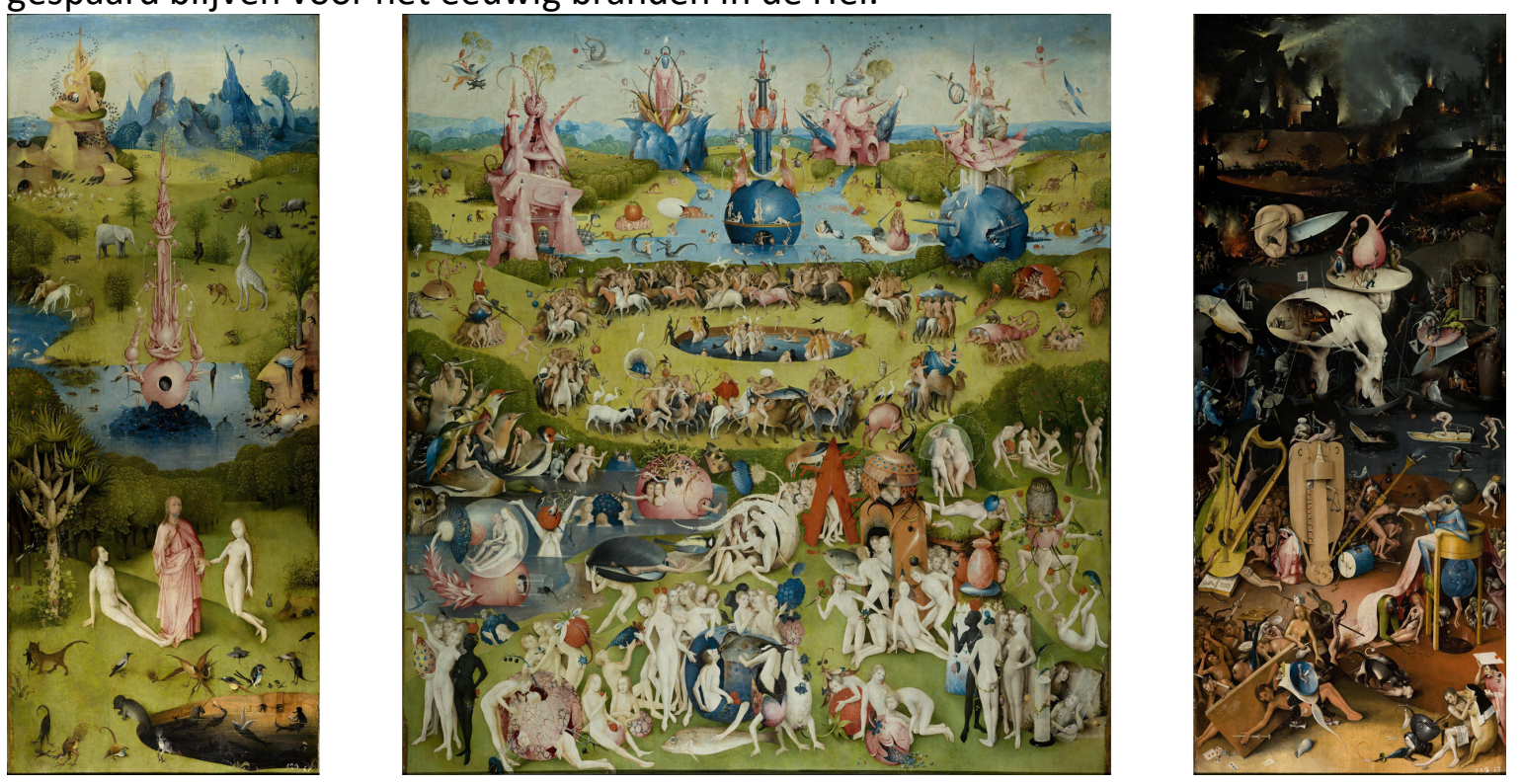

Het goede nieuws dat u mee kunt nemen van mijn oratie is dat u niet bang hoeft te zijn dat u na uw dood zult branden in de Hel. Dat gebeurt op Aarde al. Bosch heeft dit goed gezien en heeft dit verbeeld op het rechterpaneel van zijn schilderij. Dit branden was, zoals de Engelse titel misschien beter aangeeft, één van de "Earthly Delights".

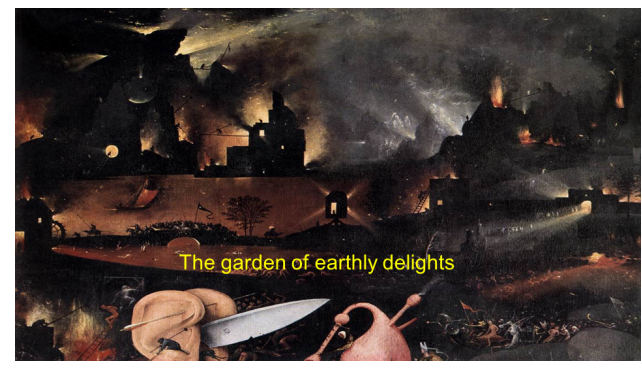

Dat branden op Aarde komt door een stof waarvan we dat in eerste instantie niet verwachten. Die stof is zuurstof. De meeste mensen denken dat zuurstof essentieel is voor hun leven. Dat is zo, maar zuurstof is ook reactief, en daardoor giftig. Net als een kaars branden we langzaam op. Dat kunnen we ook zien aan ouderdomsvlekken. Ouderdomsvlekken zijn verbrande eiwitten die het lichaam niet meer kan opruimen. Verbranden van DNA kan leiden tot kanker. 
Dat verbranden noemen we "oxidatie". Gelukkig is er een tegenkracht: "reductie". Die twee woorden samen vormen mijn onderzoeksveld "Redox". Redox zorgt voor energie, energie die essentieel is voor leven en veerkracht. Maar ook is er die paradoxale schade.

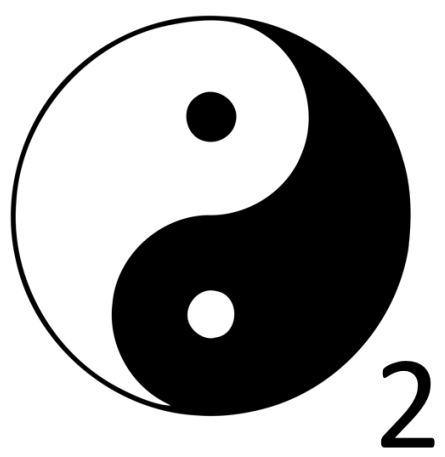

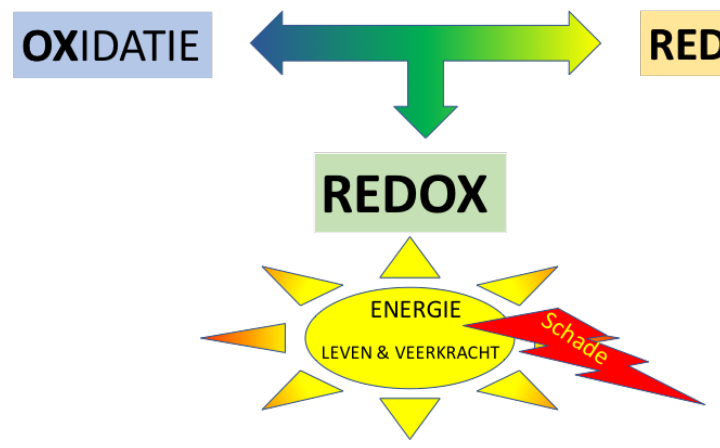

Dus zuurstof is niet zo onschuldig als het lijkt. Het bevat zowel goed als fout, Yin en Yang. Binnen deze paradox is er weer een andere paradox, sommige fouten zijn weer goed. Door die fouten ontstaan gemuteerde organismen die beter aangepast zijn. Deze fouten zorgen weer voor verbetering. Hier leren we door de fouten die worden gemaakt. Die dubbele paradox zien we ook in het Taijitu symbool. In het zwarte gedeelte van de cirkel zit een kleine witte cirkel.

In mijn vakgebied kijken we naar hoe de redox, de energie, verandert tijdens het leven, dus in de tijd. We zien dat door allerlei processen, ons lichaam die energie binnen nauwe grenzen kan houden. Dit noemen we homeostase. Hierdoor blijft de tank vol.

Het energieniveau (redox) tijdens ons leven

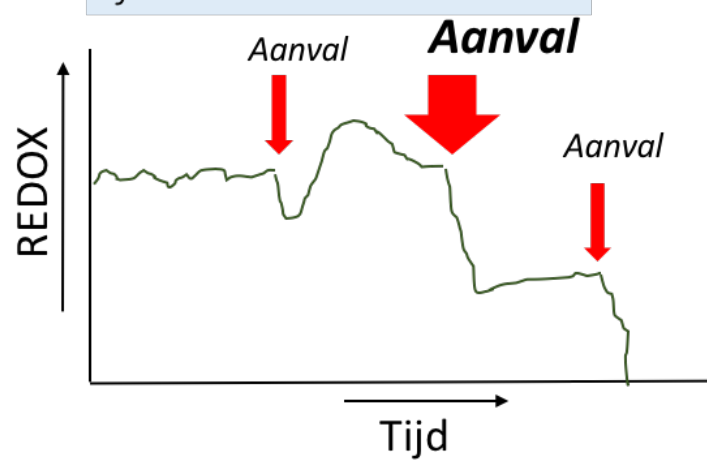

Wanneer we stress hebben, vindt er een aanval op onze energie plaats. De energie wordt minder, maar het lichaam heeft de veerkracht om de aanval op te vangen. Er vindt zelfs een tijdelijke verbetering plaats, je bouwt weerstand op. Dus een beetje slecht is zelfs goed voor je.

We hebben wel een probleem als de aanval groter, heftiger is. Bijvoorbeeld bij een chronische ziekte. De energie neemt af en een nieuw evenwicht ontstaat, met een lager energieniveau. Krijgen we dan een kleine aanval, dan kunnen we die niet meer opvangen. Alle energie vloeit weg en dan is het einde oefening.

Die veerkracht van ons lichaam, waar komt die nu vandaan? Wanneer we in een gezond organisme kijken, zien we dat heel veel processen en stoffen met elkaar verbonden zijn; er zijn erg veel connecties. Deze verbindingen
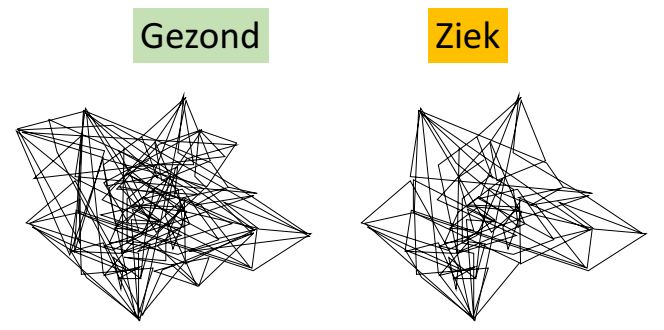
zorgen voor de veerkracht, ze vormen samen als het ware een elastisch vangnet dat een aanval gemakkelijk kan opvangen en dat kan terugveren. Wanneer we naar een ziek organisme kijken, dan zien we dat veel connecties verloren zijn gegaan, waardoor de veerkracht minder is. Het vangnet is kwetsbaar, breekbaar geworden. 


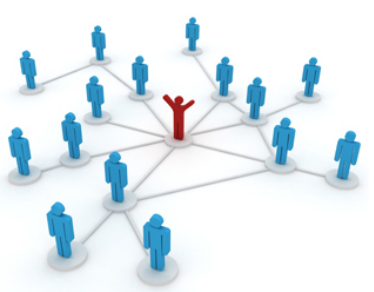

In het Engels is ziek "Illness" en gezond "Wellness". En dat geeft een leuk ezelsbruggetje ${ }^{1}$. Van "Wellness" vormen de eerste twee letters het woord "We", "wij" in het Nederlands. Als wij samen verbonden zijn, dan zijn wij gezond. Dit geldt in elke cultuur. Van "Illness" is de eerste letter "I", "ik" in het Nederlands. Als "ik" alleen ben je geïsoleerd, dat is ongezond, ziek.

In mijn vakgebied kijk ik naar de dingen die verbindingen vormen: moleculen. Hoe we dit doen wil ik illustreren met een voorbeeld: De oxidatie van lipoproteïne. Lipoproteïne zijn

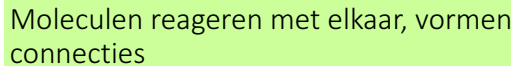
connecties

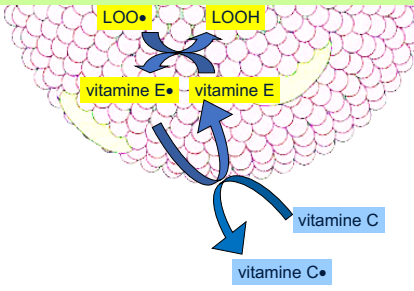

Maken van nieuwe connecties: Hydroxytyrosol verbetert communicatie tussen vitamine $\mathrm{E}$ en $\mathrm{C}$

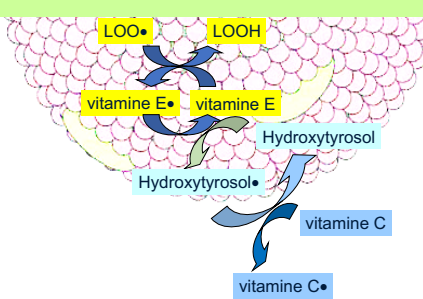
cholesterol bevattende vetbolletjes in het bloed. We weten dat oxidatie van die bolletjes leidt tot hart- en vaatziekte. Dat gebeurt doordat een vetmolecuul in het bolletje geoxideerd wordt. Dit wordt weergegeven met LOO', waarbij de punt $(\bullet)$ de reactiviteit symboliseert. Dit reactieve geoxideerde vetmolecuul kan onschadelijk gemaakt worden door een reactie met vitamine $\mathrm{E}$. Die punt $(\bullet)$, de energie, gaat dan op vitamine $E$ zitten. Het reactieve vitamine $E$ kan op zijn beurt de energie, de punt, overgeven aan vitamine $C$, die deze energie dan weer verder kan overgeven. Op die manier wordt de energie gecontroleerd afgevoerd.

We kunnen nieuwe connecties maken door stoffen toe te voegen. Eén van die stoffen is

hydroxytyrosol dat in olijfolie zit. We hebben gevonden dat hydroxytyrosol een positie inneemt tussen vitamine $\mathrm{E}$ en vitamine $\mathrm{C}$. Hydroxytyrosol verbetert zo de communicatie tussen vitamine $\mathrm{E}$ en vitamine $\mathrm{C}$. Dit is mede verantwoordelijk voor het gezondheid bevorderend effect van olijfolie ${ }^{2}$.

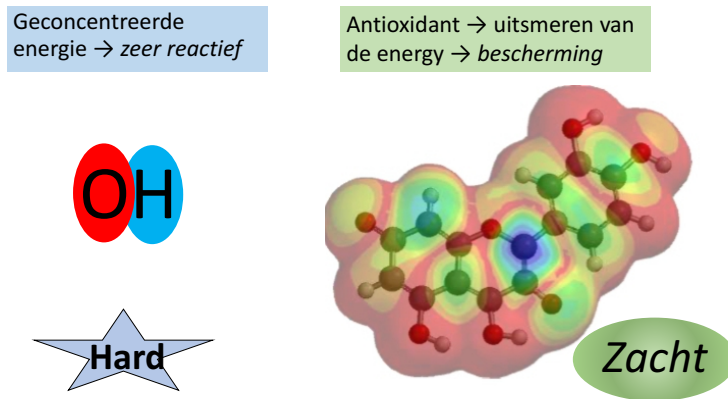

Een belangrijke vraag binnen mijn vakgebied is de vraag waarom de ene stof reactiever is dan de andere. Het blijkt dat wanneer in een stof de energie erg geconcentreerd is, op één plaats zit net als in het brandpunt van een lens, deze stof erg reactief is. Dat is het geval bij het hydroxyl radicaal, een verbinding waar alle energie op één atoom zit. Dit is dan ook de meest reactieve verbinding

die we in ons lichaam tegenkomen. Bij antioxidanten zien we dat die energie uitgesmeerd is over het hele molecuul. Door het uitsmeren neemt de reactiviteit af en daardoor kan een antioxidant de energie relatief veilig opslaan. In redox taal noemen we een stof met geconcentreerde energie "hard", en een stof met uitgesmeerde energie "zacht".

${ }^{1}$ http://magazine-on-the-spot.nl/theartofselfhealing/jan-van-de-greef.html

${ }^{2}$ Rietjens, Saskia J., Aalt Bast, and Guido RMM Haenen. Journal of agricultural and food chemistry 55.18 (2007): 7609-7614. http://pubs.acs.org/doi/abs/10.1021/jf0706934 


\section{Kijken in het molecuul}

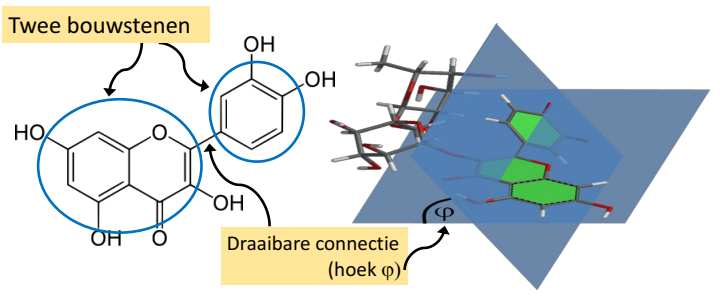

Communicatie: de hoek $\varphi$ tussen bouwstenen van het molecuul

bouwstenen, hoe zachter het molecuul. ${ }^{3}$

Kijken in het molecuul (E.S.R.)

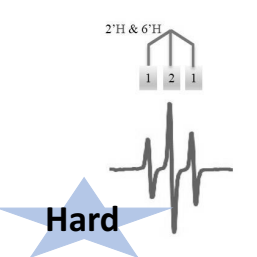

Kijken hoe het electron uitgesmeerd is over het molecuu

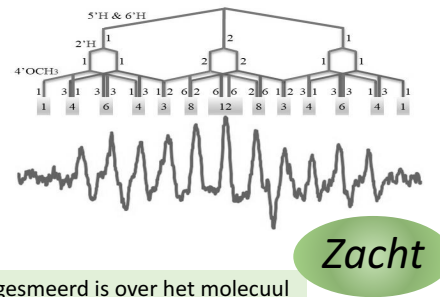

We hebben technieken waarmee we in het molecuul kunnen kijken om na te gaan hoe goed een molecuul de energie kan uitsmeren. In het voorbeeld is het molecuul opgebouwd uit twee bouwstenen, twee ringsystemen. De hoek tussen die bouwstenen bepaalt hoe goed de energie van de ene bouwsteen naar de andere bouwsteen vloeit. Hoe beter de connectie tussen de

We kunnen met een andere techniek kijken hoe de energie van een elektron over het molecuul is uitgesmeerd. Uit de scherpte van de signalen die we met deze techniek krijgen, kunnen we de hardheid bepalen. Een sterk en scherp signaal duidt op een harde stof. Een zwak en diffuus signaal duidt op een zachte stof.

We kunnen de gemeten hardheid ook berekenen met de computer. Het blijkt

dat hoe lager de met de computer berekende energie is, hoe zachter het molecuul zich gedraagt in onze testsystemen. Hiermee kunnen we nieuwe theorieën opstellen en ook
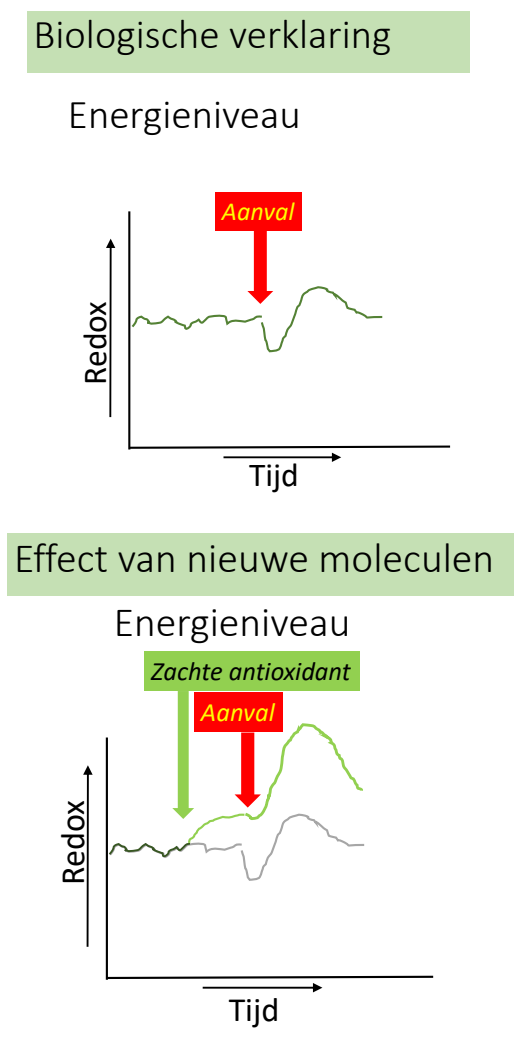
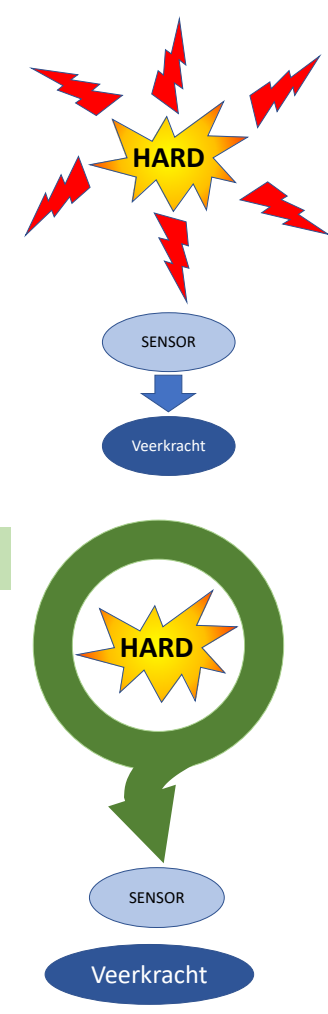
voorspellingen doen voor het gericht synthetiseren van nog zachtere, betere moleculen.

We kunnen inmiddels ook een biologische verklaring geven voor de eerder genoemde redoxveranderingen in de tijd. De aanval komt door harde energie. Die harde energie kan met alles in de cel reageren en zo de cel uiteindelijk kapot maken. In de cel zit ook een sensor die aangezet wordt door de harde energie. Door het aanzetten van die sensor gaat de cel meer antioxidanten maken. Dat zorgt voor meer veerkracht.

We weten ook wat zachte antioxidanten doen. Wanneer we een zachte antioxidant toevoegen, neemt de redox van de cel toe. Een aanval leidt dan niet alleen tot minder

${ }^{3}$ Moalin, Mohamed, et al. Molecules 16.11 (2011): 9636-9650. http://www.mdpi.com/1420- 
schade; het interessante is dat door de aanval de veerkracht extra toeneemt. De biologische verklaring hiervan kennen we ook. De harde energie wordt opgevangen door de zachte antioxidant en omgezet in zachte energie. Die zachte energie geeft weinig tot geen schade, maar kan wel heel goed de sensor aanzetten. Dit verklaart de toename van de veerkracht. ${ }^{4}$

Samenvattend, toevoegen van nieuwe moleculen aan een organisme leidt ertoe dat harde energie wordt omgezet in zachte energie. Dit zorgt voor nieuwe connecties.

Uiteindelijk verhoogt het de veerkracht.

Mijn toekomstig onderzoek is gericht op het verklaren van het verschil in effect van moleculen op de redox. Het vervolg is het ontrafelen van de dynamische interactie tussen moleculen. En tenslotte het onderzoeken van andere vormen van energie.

Energie: licht
Celkernen in
bloedvaten
lichten op na
geven van
een zachte
stof

Als we kijken naar energie vanuit een Westers perspectief dan is de volgende stap dat we gaan kijken naar energie in de vorm van licht. Dit is mede ingegeven door een toevalsbevinding. In microscoop beelden van bloedvaten van muizen die behandeld waren met een zachte stof, zagen we de celkernen oplichten. ${ }^{5}$ Het opvallende was dat we dit waarnamen lang nadat de stof uit het bloed verdwenen was. We zijn bezig te achterhalen hoe dit kan, en mijn gevoel zegt dat dit een weg is die we verder moeten vervolgen.

Een ander pad dat we opgaan is het pad van de traditionele Chinese geneeskunst. Bij deze geneeskunst wordt op een totaal andere manier tegen energie aangekeken. Deze geneeskunst gaat ervan uit dat de "vitale energie" van het lichaam (chi or qi) die alle organen en functies in het lichaam verbindt, stroomt door kanalen, genaamd "meridianen". Met Traditionele Chinese Medicatie kan het stromen van die "vitale energie" worden gecorrigeerd.

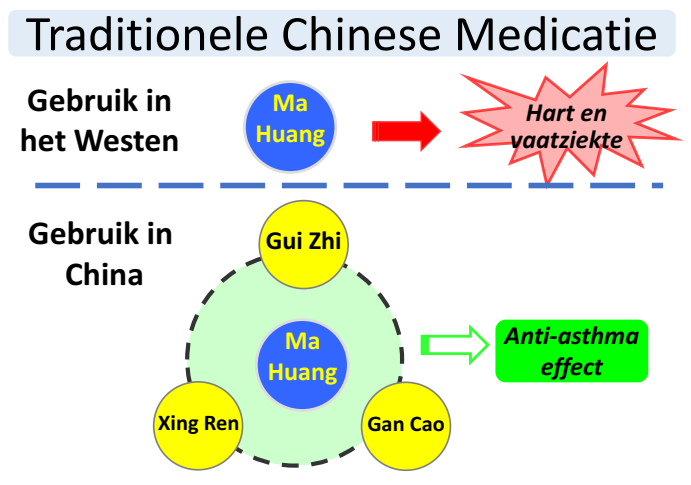

Onze eerste resultaten geven aan dat we in het Westen veel van de traditionele Chinese geneeskunst kunnen leren. In de Westerse geneeskunst wordt gewoonlijk alleen het kruid gebruikt waarin de meest potente stoffen zitten, in de veronderstelling dat dit het beste effect geeft. In de praktijk geeft die benadering veel bijwerkingen. In de Traditionele Chinese Medicatie worden juist gebalanceerde combinaties van kruiden gebruikt. Door die combinaties worden bijwerkingen voorkomen door gebruik te maken van de dynamische interactie tussen de kruiden. ${ }^{6}$ De keerzijde is dat het vaak langer duurt voordat het gewenste effect wordt verkregen.

\footnotetext{
${ }^{4}$ Lemmens, Kristien JA, et al. PharmaNutrition 2.3 (2014): 69-74. http://www.sciencedirect.com/science/article/pii/S221343441400019X

${ }^{5}$ Lemmens, Kristien JA, et al. Toxicology in vitro 28.4 (2014): 538-543. http://www.sciencedirect.com/science/article/pii/S0887233313003457

${ }^{6}$ Zhang, Ming, Misha Vrolijk, and Guido RMM Haenen. International journal of molecular sciences19.1 (2017): 18. http://www.mdpi.com/1422-0067/19/1/18
} 
Energie vanuit een Westers perspectief

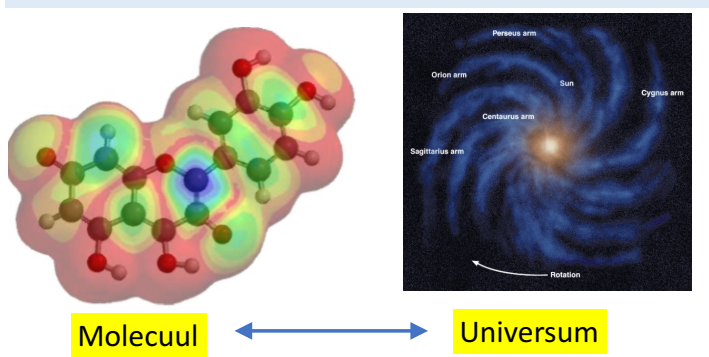

Terugkerend naar het Westers perspectief hebben we energie in de vorm van moleculen, elektronen en fotonen. Die vormen de connecties. Connecties krijg je wanneer moleculen met elkaar reageren, door een wisselwerking van elektronen en fotonen in die moleculen. De tweede hoofdwet in de thermodynamica geeft aan dat reacties tussen moleculen alleen plaatsvinden: "Wanneer de entropie

(energie) van het universum toeneemt". Er is dus een connectie tussen de energie die in het allerkleinste zit, het molecuul, en de haast onmetelijke energie van het universum. En dan hebben we nog de wetenschap dat alle moleculen in ons lichaam uiteindelijk opgebouwd zijn uit sterrenstof. Dat maakt mij in ieder geval erg nederig.

Tenslotte wil ik, en dat is waarschijnlijk het belangrijkste dat ik heb te zeggen, alle studenten, collega's en vrienden bedanken waarmee ik heb mogen samenwerken. Ik heb uiteindelijk het meeste geleerd van alle vragen die ik heb gekregen van mijn studenten; de 22 promovendi, de meer dan 200 stagiaires en de meer dan 10.000 studenten. Ik ben dan wel hoogleraar, maar blijf leerling.

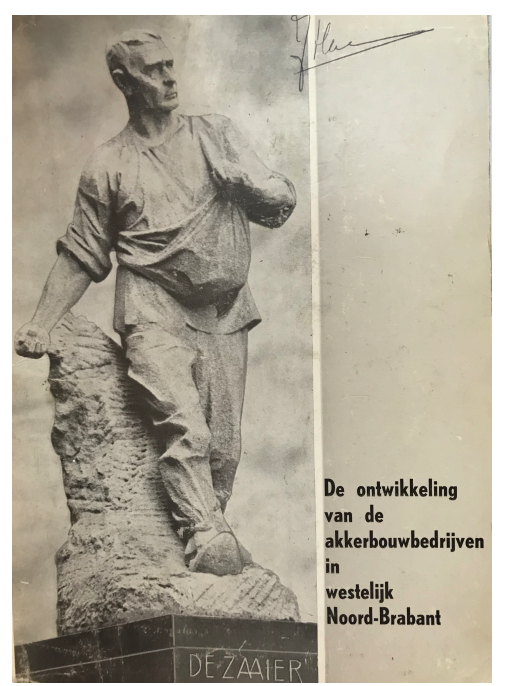

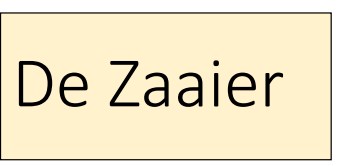

Maar er viel ook
wat zaad in goede
grond, en dat
bracht vrucht
voort, deels
honderdvoudig,
deels zestigvoudig,
deels dertigvoudig.

Ik zie in mijn hoogleraarschap overeenkomsten met de zaaier. Dit heb ik waarschijnlijk meegekregen van mijn vader. Vanuit de landbouwvoorlichting was hij erop uit om de opbrengst van de akkers te vergroten door ervoor te zorgen dat al het zaad in goede aarde viel en zo maximaal opbracht. ${ }^{7}$ Ik zie voor mij als hoogleraar meer een rol weggelegd om te zorgen voor het zaad dat tussen de distels valt, en te zorgen voor het zaad dat verloren dreigt te gaan doordat het te weinig

${ }^{7}$ De heer Haenen heeft met zijn manier van voorlichten, onder andere via talloze artikelen in dit blad, veel boeren bereikt. Toch gelooft hij, dat hij van hen minstens evenveel heeft geleerd als zij van hem. Hij stelt: "Voorlichten is vooral een kwestie van je ogen en oren goed de kost geven en deze waarnemingen aan anderen doorgeven."

Is dat gelukt? Onze gesprekspartner laat het oordeel daarover aan anderen. Glimlachend wijst hij op de gelijkenis met de parabel van de zaaier in het Evangelie. "Haast letterlijk ging het ook zo met onze voorlichtingsboodschap en met de resultaten daarvan. Een deel van de bedrijven hebben we niet kunnen bereiken. Daar vielen onze adviezen niet in goede aarde. Merkwaardigerwijs betrof dat vooral kleine bedrijven. Helaas is dat vandaag de dag nog zo. Kleine bedrijven vragen het minst om voorlichting. Dat is jammer, want zelfs heden ten dage weten kleine boeren de mogelijkheden vaak niet voldoende te benutten".

Een deel van de voorlichtingsboodschap kon geen vrucht dragen omdat er doornen groeiden: er obstakels waren: bedrijfsomstandigheden te wensen overlieten. Daaraan is veel gedaan: bijvoorbeeld door ruilverkaveling, grondverbetering, modernisering van gebouwen. "Daardoor viel uiteindelijk een groot deel van onze voorlichtingsboodschap toch in goede aarde en bracht deze veelvuldig vrucht op." ... En inderdaad: 100 kg zaadgoed per ha kan anno 1984 zelfs honderdvoudige vrucht dus $10.000 \mathrm{~kg}$ tarwe opleveren... Maar de voorlichting ten spijt, blijven allerlei aspecten altijd het oog van de meester vergen, zo vindt de heer Haenen. Herman van den Hengel, In gesprek met . . Ir Jan Haenen: Boeren kunnen van elkaar veel leren, Boer en Tuinder, 4-10-1984, Jaargang 38, nr. 1901, pagina $34-35$ 
water krijgt. Daar kan ik het verschil maken. Zodat ook dit zaad kan groeien, misschien wel tot een machtige boom. En wonder boven wonder, het is mij vrijwel altijd gelukt om iedereen over de streep te trekken. Dat was noeste arbeid. Maar ik heb het altijd met heel veel plezier gedaan. Ik hoop de kracht en energie te behouden om dit te blijven doen. Dat het zaadje dat in mij wortel heeft geschoten niet verdort en vrucht blijft geven. Dat ik vol verwondering de wereld kan blijven inkijken en daarvan kan blijven genieten.

Tenslotte wil ik u een lied aanbieden dat misschien beter uitbeeldt wat ik wil zeggen. Ik heb aan dit lied de titel van mijn oratie ontleend. Maar misschien wel belangrijker in dit lied is de zin: "Life is for learning". We leren het meest van de fouten die wij en die anderen maken. We moeten elkaar daarbij helpen en respecteren. En ondertussen het genieten niet vergeten. "We got to get ourselves back to the garden".

Ik heb gezegd.

Woodstock (Joni Mitchell)

https://www.youtube.com/watch?v=3aOGnVKWbwc

Well, I came upon a child of God

He was walking along the road

And I asked him, Tell me, where are you going

This he told me

Said, I'm going down to Yasgur's Farm

Gonna join in a rock and roll band

Got to get back to the land and set my soul free

We are stardust, we are golden

We are billion year old carbon

And we got to get ourselves back to the garden

Well, then can I roam beside you?

I have come to lose the smog,

And I feel myself a cog in somethin' turning

And maybe it's the time of year

Yes and maybe it's the time of man

And I don't know who I am

But life is for learning

We are stardust, we are golden

We are billion year old carbon

And we got to get ourselves back to the garden

We are stardust, we are golden

We are billion year old carbon

And we got to get ourselves back to the garden

By the time we got to Woodstock

We were half a million strong

And everywhere was a song and a celebration

And I dreamed I saw the bomber death planes

Riding shotgun in the sky,

Turning into butterflies

Above our nation 
We are stardust, we are golden

We are caught in the devils bargain

And we got to get ourselves back to the garden

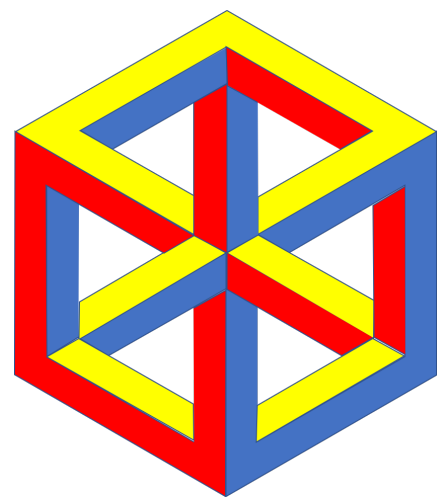

